\author{
G.K. Burkeyeva \\ Ye.A. Buketov Karaganda State University, Kazakhstan \\ (E-mail: guls_b@mail.ru)
}

\title{
Investigation of copolymers based on unsaturated polyester resins
}

\begin{abstract}
The possibility of controlling the properties of network copolymers of polyethylene glycol maleate by changing external factors ( $\mathrm{pH}$ of medium, temperature, the presence of organic solvents and low molecular weight inorganic salts) has been studied. Swelling capacity of the copolymers investigated was studied using gravimetric method. It has been established that the hydrogels are sensitive to the change of $\mathrm{pH}$ of medium and the copolymers' samples undergo reversible swelling-collapse-swelling transfer. Basic factors which determine the swelling of the gels studied are electrostatic repulsion of similarly charged carboxylic groups and appearance of opposite charges on macrochains as a result of the hydrolysis of acrylamide segments. It has been shown that the hydrogels of polyethylene glycol maleate with acrylamide are sensitive to the influence of temperature and the dependence of the swelling degree has extreme character. The sensitivity of the copolymers to the presence of low molecular salts has been established. Combined regimen of their behavior in the presence of salts is due to the hydrolysis of amide bond in the segments of the copolymer of polyethylene glycol maleate. When adding organic solvent to the medium which is the polymer swollen in water continuous contraction of the samples studied is observed and it leads to the shrinkage of the hydrogels' size. Suppressive action of organic solvents on swelling of the copolymers of polyethylene glycol maleate with acrylamide is explained by the polarity of the solvents.
\end{abstract}

Keywords: unsaturated polyesters, unsaturated polyester resins, copolymerization, polyethylene glycol maleate, acrylamide, copolymer, hydrogel, swelling.

\section{Introduction}

In today's world of technology it is difficult to remain a competitive manufacturer of quality products in the global market. The main criterion for competitive production is the use of affordable, accessible, and preferably renewable raw materials with minimal operating cost. The products based on unsaturated polyester resins are promising in this area. Currently, being leaders among composite materials, unsaturated polyester resins are used increasingly due to the ease of obtaining, and availability of raw materials. In particular, polyglycolmaleates and polyglycolfumarates in combination with other di- and monocarboxylic acids are easily cured by vinyl monomers. Products based on unsaturated polyester resins cured with vinyl monomers have specific physico-chemical and mechanical properties, combined with low toxicity and relative accessibility. Due to the characteristics described production of decorative materials and products for constructional purposes made on the basis of unsaturated polyester resins develops rapidly.

The researchers pay particular attention to the so-called super moisture sorbents or hydrogels. The unique properties of polymeric hydrogels offer great opportunities for the practical application of these materials in medicine, biotechnology, ecology, plant, solar energy and other fields of industry and science. Providing highly efficient functioning of hydrogels in different practical tasks determines the need for understanding the behavior of this class of polymers in different environments and relevance of carrying out the basic research in this direction. Understanding and quantification of the laws of the swelling and the elastic behavior of polymeric hydrogels are of fundamental importance.

Unsaturated polyester resins with acrylamide are basic for the preparation of such polymers. We propose a new method for producing hydrogels based on polyethyleneglycolmaleate in the thesis presented.

Weakly linked hydrogel networks which are able to react immediately to little changes of external factors (ionic strength of the solution, $\mathrm{pH}$ of medium, temperature and others) is a big class of the compounds called «intelligent materials» among the scientists of this field. These properties of crosslinked polymers define their use as functional materials in different fields (agriculture, hydrometallurgy, medicine, oil-refining and many others).

There is data on copolymerization of unsaturated polyester resins with acrylates in literature [1-3], however there is no information on similar reactions of unsaturated carboxylic acids with acrylamides.

In this regard the reactions of radical copolymerization of polyethylene glycol maleate with acrylamide in the solution have been investigated in this work. 


\section{Experimental part}

Polyethylene glycol maleate (p-EGM) was obtained by the reaction of polycondensation of maleic anhydride with ethylene glycol at 393-403 K [4]. The process was controlled by determining acidic number and by the volume of water eliminated.

Molecular mass of p-EGM has been determined using light scattering method on nephelometer $2100 \mathrm{AN}(\mathrm{NACH})$ and using gel permeation chromatography on Agilent 1260 Infinity which was equal to 2350 a.m.u.

Radical copolymerization of p-EGM with acrylamide (AA) was carried out in solution at the ratio of monomers with the solvent 1:1.5 (on mass) at various initial molar ratios of the comonomers in the presence of dinitrile of azo-bis-isobutyric acid (AIBN) as an initiator at a temperature of $333 \mathrm{~K}$.

Synthesized polymers were washed with dioxane for purifying from unreacted monomer residues. The composition of the copolymers obtained has been determined potentiometrically and according to the residual amount of the monomers using gas chromatography [5].

Equilibrium swelling degree of the polymers was measured gravimetrically. The amount of liquid absorbed was determined on mass of swollen sample. Swelling degree of the gel $\alpha$ was calculated as a relation of the mass of swollen hydrogel at a equilibrium swelling point to its mass at dry state:

$$
\alpha=\frac{m-m_{0}}{m_{0}} 100 \% \text {. }
$$

\section{Results and discussion}

The presence of unsaturated double bonds in the molecules of p-EGM allows to use the latter as a matrix for obtaining network copolymers when polymerizing with highly reactive acrylamide. In this regard the attempt to obtain such polymers by the reaction of p-EGM with AA has been made by our group. Data on copolymerization of p-EGM with AA are given in Table.

$\mathrm{T} \mathrm{a} \mathrm{b} 1 \mathrm{e}$

Dependence of composition of the copolymers on the composition of initial mixture
when copolymerizing p-EGM $\left(\mathrm{M}_{1}\right)$ with AA $\left(\mathrm{M}_{2}\right)$, AIBN $[\mathrm{I}]=8 \mathrm{~mol} / \mathrm{m}^{3}, \mathrm{~T}=333 \mathrm{~K}$

\begin{tabular}{|c|c|c|c|c|c|}
\hline \multicolumn{2}{|c|}{ Initial monomer ratios, mol. $\%$} & \multicolumn{2}{|c|}{ Composition of the copolymers, mol. \% } & \multirow{2}{*}{$\alpha, \%$} & \multirow{2}{*}{ Yield, $\%$} \\
\cline { 1 - 4 } $\mathrm{M}_{1}$ & $\mathrm{M}_{2}$ & $m_{1}$ & $m_{2}$ & 166.2 & 48.7 \\
\hline 9.99 & 90.01 & 8.21 & 91.79 & 154.0 & 42.4 \\
\hline 24.99 & 75.01 & 22.13 & 51.18 & 133.1 & 37.9 \\
\hline 50.04 & 49.96 & 48.82 & 26.36 & 129.5 & 31.5 \\
\hline 75.06 & 24.94 & 73.64 & 11.67 & 104.3 & 28.7 \\
\hline 90.16 & 9.84 & 88.33 & & & \\
\hline
\end{tabular}

With the aim of estimating the swelling capacity of the synthesized copolymers the influence of temperature, $\mathrm{pH}$ of medium, ionic strength of solution and the mixtures «organic solvent - water» on properties of the studied samples has been investigated.

Temperature is one of the external factors which allows to fulfill potential abilities of polymeric gels to various extents. Depending on their chemical composition hydrogels can be stable to the changes of temperature or they may swell or collapse at increasing the temperature or combine both types of behaviour. There are the results of the study of the influence of temperature on swelling of the copolymers of p-EGM-AA below (Fig. 1).

When submerged into the water of room temperature $20^{\circ} \mathrm{C}$ the copolymer of p-EGM-AA swells and at increasing the temperature till some critical meaning the ability of hydrogel to absorb water decreases; further heating of the system leads to inverse temperature dependence: reversible transition «swelling-collapseswelling» is observed. Complex character of the dependence of swelling degree on temperature justifies that several types of interactions are responsible for the behaviour of hydrogel. The forces which cause collapse of the gel can be interaction of hydrophobic fragments of macrochains accompanied by the displacement of the molecules of water structured near the surface of these groups. It has been shown in a number of works [6] that phase transitions are enhanced when incorporating small parts of charged segments. The system investigated is weakly charged, but there can appear additional charges as a result of the hydrolysis of 
active functional groups. The hydrolysis degree depends on temperature, therefore it can affect on the studied dependence. In this case $\mathrm{NH}_{2}$ group of AA can be hydrolyzed and similarly charged functional groups are formed as it was found out by Tanaka [7, 8]. Then the hydrolysis of acrylamide segments helps to swelling of the copolymers.

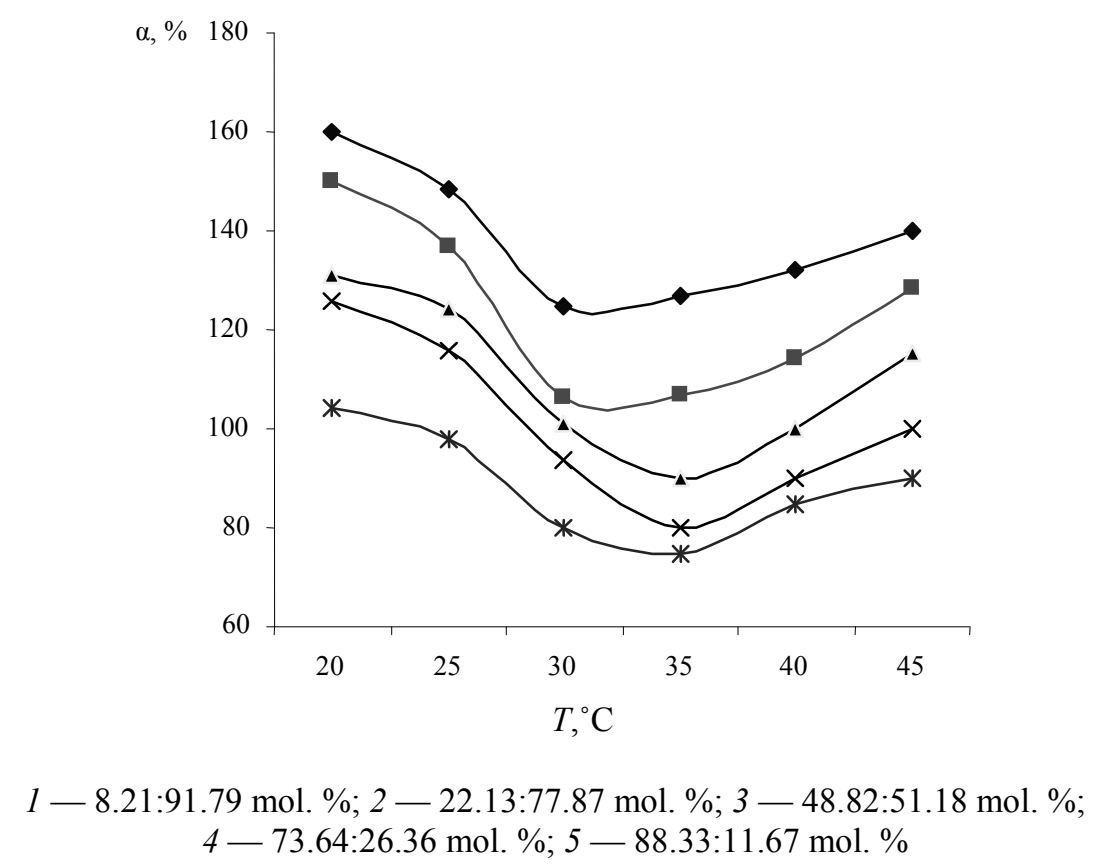

Figure 1. Influence of temperature on swelling of the gels based on p-EGM-AA

One of the important external factors which is able to influence considerably on physicochemical behaviour of polymeric gels is $\mathrm{pH}$ of medium. Ionogenic polymers either swells in the solution with increasing the $\mathrm{pH}$ of medium or collapse, but in case of polyampholytic gels they combine both types of behaviour. The results of the investigations of the influence of $\mathrm{pH}$ of medium on behaviour of hydrogels of the copolymers of p-EGM-AA are shown below.

Experimental data on the influence of $\mathrm{pH}$ of medium on swelling ability of the studied samples of p-EGM-AA are given in Figure 2. It is seen from graphical data that the dependence has extreme character with the minimum of swelling at $\mathrm{pH}$ close to acidic.

The character of dependence curve shows that the gel is polyampholytic i.e. it contains acidic and basic groups in macrochains. In our opinion the minimum on the curve of dependence of swelling degree on $\mathrm{pH}$ of p-EGM-AA can be explained by decreasing osmotic pressure of counter ions as well as Coulombic attraction of oppositely charged segments. With increasing the content of AA segments in the copolymers the $\mathrm{pH}$ area corresponding to the sorption capacity of the hydrogel shifts to more basic part. The reason for that could be partial hydrolysis of acrylamide segments. As the concentration of the AA segments in macrochain is more relating to the segments of p-EGM even small part of hydrolyzed acrylamide groups can make considerable influence on the process. As a result of the formation of excessive negative charge by hydrolyzed acrylamide chains the compensation which leads to the collapse of the gel of polymeric network of p-EGMAA of composition 8.21:91.79 mol. \% occurs at higher $\mathrm{pH}$ meanings.

When designing polymeric materials with given properties it is necessary to take into account the influence of low molecular compounds, in particular, the influence of salts. Mainly it relates to the gels with high content of ionized groups. Investigations which have been done before [9] on the copolymers of polyethylene glycol maleate with some vinyl monomers and the results presented above have shown that the latter show polyelectrolytic and polyampholytic properties. This presupposes the susceptibility of the gels studied to the ions of low molecular salts.

The influence of mono- and bivalent salts $\mathrm{NaCl}$ and $\mathrm{CaCl}_{2}$ correspondingly on swelling of the copolymers of p-EGM-AA has been studied in this work. 


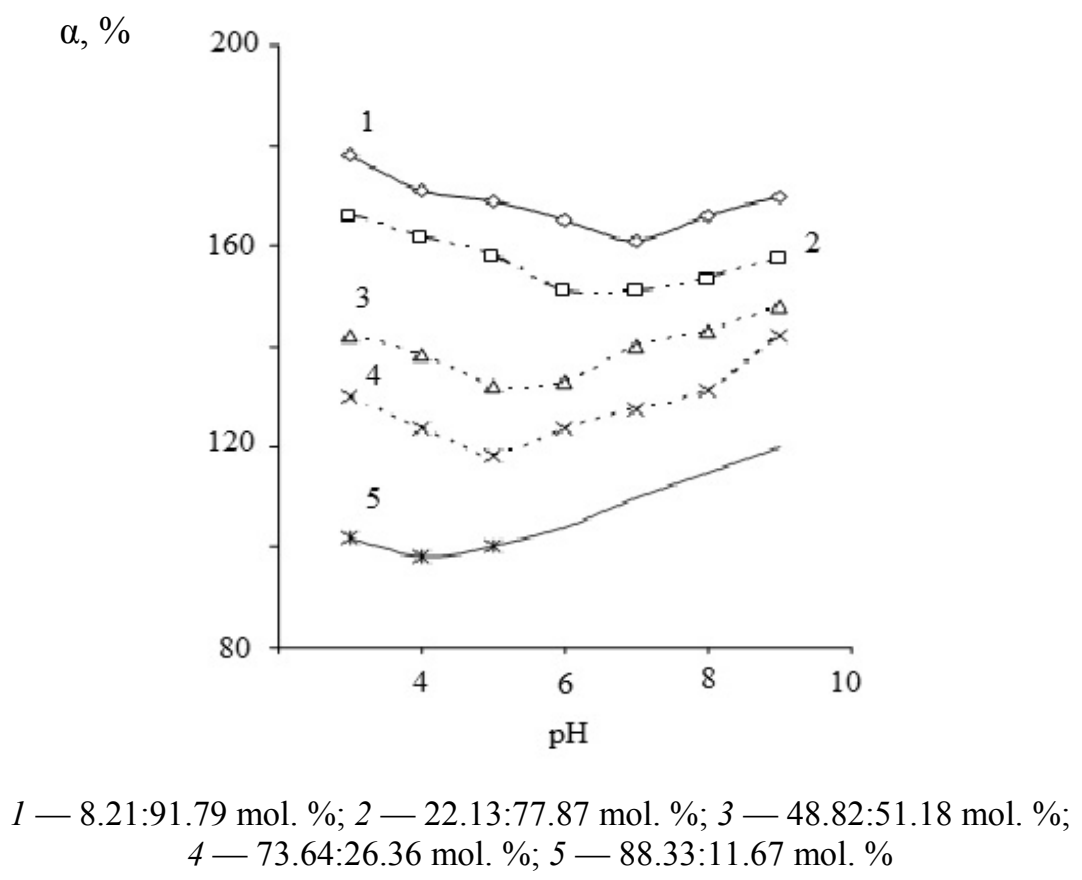

Figure 2. Influence of $\mathrm{pH}$ of medium on behaviour of hydrogels on the basis of the copolymers of $\mathrm{p}-\mathrm{EGM}-\mathrm{AA}$

Experimental data on swelling the gels on the basis of p-EGM-AA in dependence of concentration of $\mathrm{NaCl}$ are presented on Figure 3. When adding low molecular salt $(\mathrm{NaCl})$ to the external solution the size of the sample of polymeric network decreases to some minimal meaning/point. In our point of view this kind of behaviour is explained by the fact that the dependence of swelling degree of the copolymer of p-EGM-AA on concentration of the salt goes in accordance with polyampholytic regimen. As a result of the hydrolysis of acrylamide segments equally charged groups are formed and electrostatic repulsion occurs. Incorporation of the electrolyte (in this case $\mathrm{NaCl}$ ) to the solution leads to the screening of electrostatic repulsion of similarly charged groups. At certain concentration of the salt when amine groups are screened and there are excessive content of carboxylic groups under the thrusting pressure of counter ions sudden swelling of the gel occurs. This kind of behaviour is characteristic for polyampholytic gels [6].

According to the results obtained the ratio of monomer segments in the copolymers influences on the behaviour of the hydrogels to the presence of low molecular salts. So with increase of the portion of AA in the copolymers the susceptibility of the gels to the addition of the salts increases and volume-phase transition is observed at higher meanings of concentrations of the salts. This can be due to increase of the number of similarly charged groups formed as a result of the hydrolysis of acrylamide and suppression of electrostatic repulsion takes place at much higher concentrations.

Continuing the study the influence of bivalent salt $\mathrm{CaCl}_{2}$ on the behaviour of the hydrogels of p-EGMAA has been considered. On Figure 4 experimental data on swelling of the copolymers of p-EGM-AA in the presence of bivalent salt are shown. The character of the dependence curve of swelling the copolymers in the presence of $\mathrm{CaCl}_{2}$ and $\mathrm{NaCl}$ is similar. It is necessary to note that decrease of sorption capacity of hydrogels is observed at much lower concentrations of bivalent salts. This can be caused by different reasons [7]. Firstly, bivalent ions are attracted stronger to the oppositely charged groups of the network than monovalent salts. Secondly, bivalent salts are able to neutralize the charge of a big numbers of counter ions inside of the network.

The ability of the hydrogels to swell depends on nature of the solvent with which it is surrounded. In previous chapters it has been shown that the copolymers of p-EGM-AA swell considerably in water in conditions of neutral meanings of $\mathrm{pH}$, at room temperature and in absence of low molecular electrolytes. However it is interesting from theoretical and practical point of view to know the behaviour of crosslinked polymers in mixed water-organic solvents. 


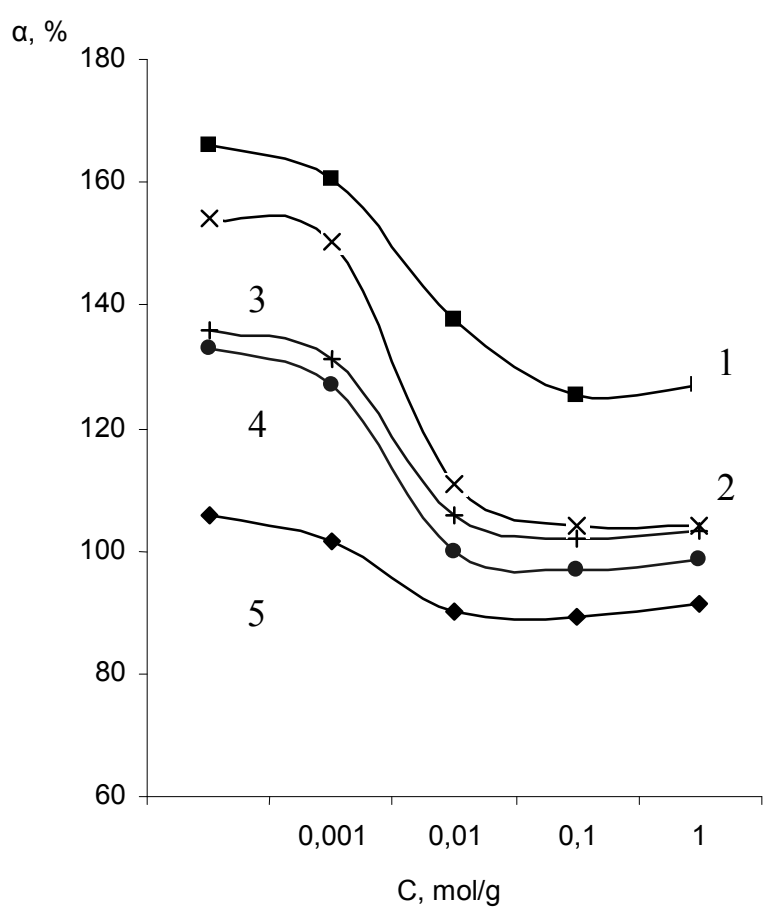

$1-8.21: 91.79$ mol. \%; $2-22.13: 77.87$ mol. \%; $3-48.82: 51.18 \mathrm{~mol} . \%$; $4-73.64: 26.36$ mol. \%; $5-88.33: 11.67$ mol. \%

Figure 3. Influence of concentration of $\mathrm{NaCl}$ on swelling of the gels based on $\mathrm{p}-\mathrm{EGM}-\mathrm{AA}$

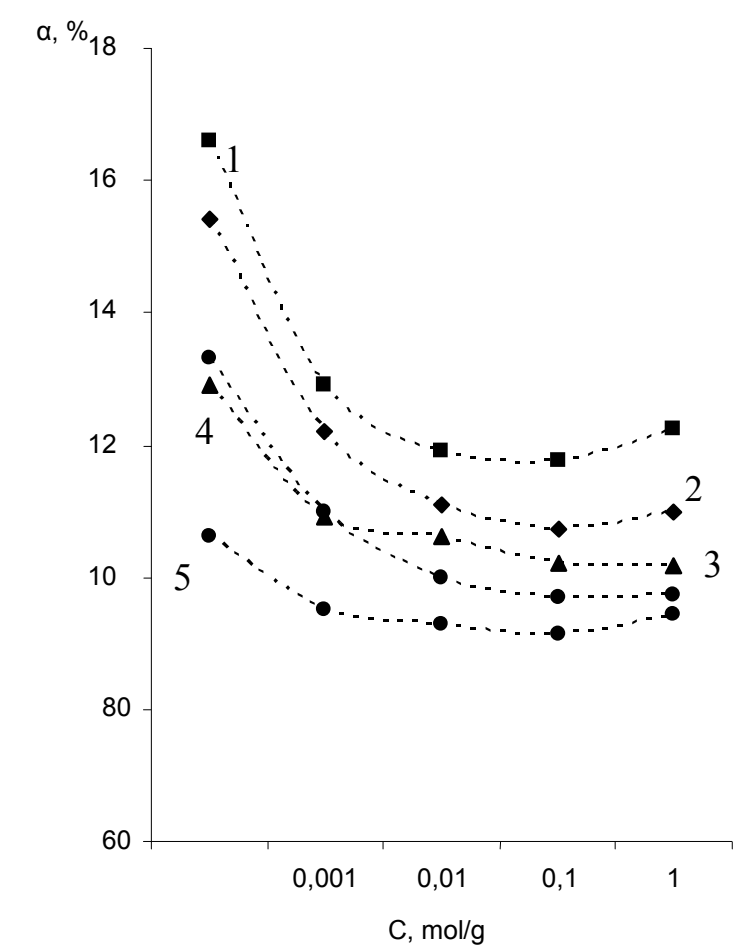

$1-8.21: 91.79$ mol. \%; $2-22.13: 77.87$ mol. \%; $3-48.82: 51.18$ mol. \%; $4-73.64: 26.36$ mol. \%; $5-88.33: 11.67$ mol. \%

Figure 4. Influence of concentration of $\mathrm{CaCl}_{2}$ on swelling of the gels based on p-EGM-AA 
In this regard the influence of the composition of binary mixtures water-organic solvents on volume characteristics of the gels on the basis of the copolymers of p-EGM-AA has been investigated. As it is seen in Figure 5 the solvents with different thermodynamic parameters such as ethanol, dimethyl formamide (DMF), dimethyl sulfoxide (DMSO) have been chosen for the analysis of the behaviour of hydrogels of p-EGM-AA and its charged form. Their unlimited capacity to mix with water allows to vary the content of organic solvent from 0 to 1 volume portion.

$\alpha, \%$

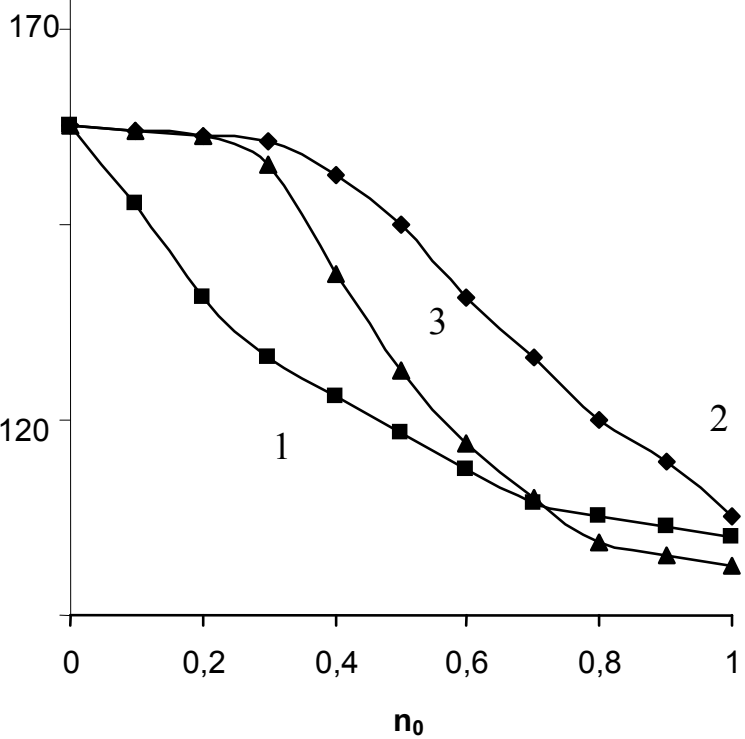

1 - water - ethanol; 2 - water - DMF; 3 - water - DMSO

Figure 5. Influence of volume fraction of organic solvent $\left(n_{0}\right)$ on swelling of the hydrogels based on the copolymer of p-EGM-AA 8.21:91.79 mol. \%

When observing the swelling of the copolymers in separate solvents it has been found out that from the range of studied low molecular mediums water is the most suitable for swelling of the copolymers of p-EGM.

When adding organic solvent to the medium which was polymer swollen in water the shrinkage of the volumes of hydrogel samples was observed. Depending on the nature of comonomers and the composition of the copolymers of p-EGM-AA the contraction has the type of continuous transition. It might be the result of the attraction of macromolecules' chains to each other which depends on the presence of charged segments. It should be noted that the function $\alpha\left(\mathrm{n}_{0}\right)$ changes not spasmodically and this process should not be considered as phase transition.

It is also necessary to note that the nature of organic solvent influences on the character of the dependence curves. So the hydrogels are more globular in ethanol in comparison with such systems as DMF-water and DMSO-water. This phenomenon can be explained by the polarity meanings and dielectric penetrability of organic components considered.

\section{Conclusion}

So a brief review of the material given in this article shows that as a result of copolymerization of polyethylene glycol maleate with acrylamide novel polymers of network structure has been obtained. The results demonstrate the opportunities of directed control over physicochemical properties of the copolymers on the basis of polyethylene glycol maleate and acrylamide induced by the composition of the polymer and by the changes of external factors ( $\mathrm{pH}$, temperature, nature of the solvent, ionic strength of the solution) which allows to develop novel materials with preliminarily programmed behaviour. 


\title{
References
}

1 Anisimov, Yu.N., Vonsovich, N.A., \& Grehova, O.B. (1996). Grafting polymerization of vinyl acetate with unsaturated oligoether resin and characteristics of hardened compositions. J. Applied Chem., 69, 2, 312-316.

2 Sedov, L.N., Avdeyeva, G.M., Zilberman, Y.G., Pugachevskaya, N.F., \& Savicheva, O.I. (1970). Modification of chemical structure of polymaleates and polyfumarates for controlling the properties of the copolymers on their basis. Herald of Tech. and Econ. Inform., 2, 16.

3 Studentsov, V.N., Cheremukhina, I.V., \& Levkin, A.N. (2003). Compositional material on the basis of unsaturated polyester resin. Informational page. Saratov: CScTechI, 5.

4 Burkeyev, M.Zh., Tazhbayev, E.M., Mustafin, E.S., Fomin, V.N., \& Magzumova, A.K. (2008, 26.12). Method of obtaining of unsaturated polyester resin from maleic acid and ethylene glicol. Innovational patent 31799/02.

5 Burkeyev, M.Zh., Tazhbayev, E.M., Burkeyeva, G.K., \& Kovaleva, A.K. (2015). Nanocatalytic Systems Based on Poly(ethylene glycol maleate) - Acrylamide Copolymers. Russian Journal of Applied Chemistry, 2(88), 314-319.

6 Burkeyeva, G.K., \& Van Herk, A.M. (2016). Constants and parameters of radical copolymerization of polyethylene glycol maleate with acrylamide at high conversion degree. Bulletin of the Karaganda University, 2(82), $23-27$.

7 Tanaka, T. (1978). Collaps of gels and the critical end point. Phys. Rev. Lett., 40, 12, 820-823.

8 Tanaka, T., Fillmore, D., Sun, S.T., Nishio, I, Swislow, G., \& Shan, A. (1980). Poly-(L-glutamic acid) poly(oxyethylene)glycol systems: perpetuated cholesteric liquid crystal structures in noncrosslinked and crosslinked solid films. Phys. Rev. Letters, 45, 20, 1636-1649.

9 Burkeyev, M.Zh., Tazhbayev, Y.M., \& Burkeyeva, G.K., et al. (2013). Influence of external factors on swelling of hydrogels on the basis of polyethylene glycol maleate with some vinyl monomers. J. Appl. Chem., 86, 1, 68-73.

\section{Г.К. Буркеева}

\section{Қанықпаған полиэфир шайыр негізінде сополимерлерді зерттеу}

Сыртқы факторлардың (pH, температура, органикалық еріткіштер және төмен молекулалық салмағы бейорганикалық тұз) өзгеруі арқылы полиэтиленгликольмалеинат сополимерінің торлану қасиетін бақылау мүмкіндігі зерттелді. Гравиметрия әдісімен зерттеліп жатқан сополимерлердің ісіну қабілеті зерттелді. Гидрогельдердің ортаның $\mathrm{pH}$ өзгерісіне тәуелді екендігі, сонымен қатар сополимерлер ісіну - коллапс - ісіну типінде қайтымды үрдістер жүретіндігі анықталды. Зерттеліп отырған гельдердің ісінуінің негізгі факторларына бірдей зарядталған карбоксил топтарының электростатикалық тебіліс әсері және акриламид тобының гидролизі нәтижесінде қарама-қарсы зарядталған бөлшектердің пайда болуы жатады. Полиэтиленгликольмалеинат пен акриламид гидрогельдері температура әсеріне тәуелді, сонымен қатар тәуелділік экстремалды қасиет көрсетеді. Сополимерлердің төмен молекулалық тұздардың қатысына тәуелділік көрсететіні анықталды. Олардың тұздар қатысында аралас жүйе көрсететіндігі полиэтиленгликольмалеинат сополимерлердің буындарындағы амид байланыстарының гидролизіне негізделген. Суда ісінген полимер түріндегі ортаға органикалық еріткішті қосқан кезде зерттеліп отырған сынамалардың үздіксіз контракциясы байқалды, сәйкесінше, бұл гидрогельдердің мөлшерінің қысқаруына әкеледі. Полиэтиленгликольмалеинат пен акриламид сополимерлерінің ісінуіне органикалық еріткіштердің әсері еріткіштердің полярлығы тұрғысынан түсіндіріледі.

Кілт сөздер: қанықпаған полиэфир, қанықпаған полиэфир шайыры, сополимерлену, полиэтиленгликольмалеинат, акриламид, сополимер, гидрогель, ісіну.

\section{Г.К. Буркеева}

\section{Исследование сополимеров на основе ненасыщенных полиэфирных смол}

\begin{abstract}
Исследована возможность управления свойствами сетчатых сополимеров полиэтиленгликольмалеината посредством изменения внешних факторов: $\mathrm{pH}$ среды, температуры, присутствия органических растворителей и низкомолекулярных неорганических солей. Методом гравиметрии изучена набухающая способность исследуемых сополимеров. Установлено, что гидрогели восприимчивы к изменению $\mathrm{pH}$ среды, при этом образцы сополимеров претерпевают возвратный переход типа набуханиеколлапс-набухание. Основополагающими факторами, определяющими набухание исследуемых гелей, являются электростатическое отталкивание одноименно заряженных карбоксильных групп и возникновение противоположных зарядов на макроцепях в результате гидролиза акриламидных звеньев. Показано, что гидрогели полиэтиленгликольмалеината с акриламидом восприимчивы к воздействию температуры, зависимость степени набухания носит экстремальный характер. Установлена восприимчивость сополимеров к присутствию низкомолекулярных солей. Смешанный режим их поведения в присутствии соли обусловлен гидролизом амидной связи в звеньях сополимера полиэтиленгликольмалеината. При прибавлении к среде, представляющей собой набухший в воде полимер, органического растворителя наблюдается непрерывная контракция исследуемых образцов, что приво-
\end{abstract}


дит к сокращению размеров гидрогелей. Подавляющее действие органических растворителей на набухание сополимеров полиэтиленгликольмалеината с акриламидом объясняется с позиции полярности растворителей.

Ключевые слова: ненасыщенный полиэфир, ненасыщенная полиэфирная смола, сополимеризация, полиэтиленгликольмалеинат, акриламид, сополимер, гидрогель, набухание. 